\title{
KARAKTERISTIK UNDANG-UNDANG KETENAGAKERJAAN DALAM PERLINDUNGAN HUKUM TERHADAP TENAGA KERJA
}

\author{
Ujang Charda S. \\ Dosen Tetap Fakultas Hukum Universitas Subang \\ E-mail: ujangch@gmail.com
}

\begin{abstract}
Laws Number 13 Year 2003 on Manpower characterized the law responsive or characterless law conservative/orthodox, then the indicators to determine the character can be seen from the manufacturing process, which is not participatory, and views of the nature of the product function of law is not aspirational, whereas any interpretations have clearly opens up opportunities for different interpretations by various regulations advanced by unilateral vision of the government and not just a technical problem. Thus, it can be concluded that Laws Number 13 of 2003 is a legal product that is characterized by a conservative/orthodox.
\end{abstract}

Keywords: characteristic; laws; employment.

\begin{abstract}
Abstrak
Undang-Undang Nomor 13 Tahun 2003 tentang Ketenagakerjaan berkarakter hukum responsif atau berkarakter hukum konservatif/ortodoks, maka indikator-indikator untuk menentukan karakter tersebut dapat dilihat dari proses pembuatan, yaitu tidak bersifat partisipatif, dan dilihat dari sifat fungsi produk hukumnya adalah tidak aspiratif, sedangkan adanya kemungkinan penafsiran telah jelas membuka peluang terjadinya berbagai interpretasi dengan berbagai peraturan lanjutan yang berdasarkan visi sepihak dari pemerintah dan tidak sekedar masalah teknis. Dengan demikian, dapat disimpulkan bahwa Undang-Undang Nomor 13 Tahun 2003 adalah merupakan suatu produk hukum yang berkarakter konservatif/ortodoks.
\end{abstract}

Kata Kunci: Karakteristik, Undang-Undang, Ketenagakerjaan.

\section{A. PENDAHULUAN}

Pembangunan ketenagakerjaan mempunyai banyak dimensi dan keterkaitannya tidak hanya dengan kepentingan tenaga kerja sebelum, selama dan sesudah masa kerja, tetapi juga dengan kepentingan pengusaha, pemerintah, dan masyarakat. Oleh karena itu, diperlukan pengaturan yang menyeluruh dan komprehensif, antara lain mencakup perencanaan tenaga kerja, pembangunan sumber daya manusia, perluasan kesempatan kerja, pelayanan penempatan tenaga kerja, pembinaan hubungan industrial, peningkatan perlindungan tenaga kerja, serta 
peningkatan produktivitas kerja dan daya saing tenaga kerja di dalam dan di luar negeri.

Dikeluarkannya Undang-Undang Nomor 13 Tahun 2003 tentang Ketenagakerjaan merupakan jawaban atas political will pemerintah dalam lapangan hukum ketenagakerjaan yang mempunyai tujuan luhur bagi perlindungan hukum terhadap tenaga kerja dalam hal: ${ }^{1}$

a. Memberdayakandanmendayagunakan tenaga kerja secara optimal dan manusiawi.

b. Mewujudkan pemerataan kesempatan kerja dan penyediaan tenaga kerja yang sesuai dengan kebutuhan pembangunan nasional dan daerah.

c. Memberikan perlindungan kepada tenaga kerja dalam mewujudkan kesejahteraan.

d. meningkatkan kesejahteraan tenaga kerja dan keluarganya.

Tujuan tersebut merupakan argumen politik para pembentuk undangundang yang dimuat dalam Pasal 4 Undang-Undang Nomor 13 Tahun 2003 tersebut di atas adalah sangat jelas dan mempunyai tujuan yang baik dengan asumsi dasar, bahwa hukum merupakan produk politik yang memiliki karakter sebagai produk hukum yang dapat dilihat apakah berkarakter hukum responsif, seperti yang dikemukakan oleh Nonet dan Selznick atau berkarakter hukum ortodoks, seperti yang dikemukakan Marryman. $^{2}$ Untuk mengetahui apakah Undang-Undang Nomor 13 Tahun 2003 berkarakter hukum responsif atau berkarakter hukum ortodoks, maka dalam studi ini digunakan indikator dalam proses pembuatan hukum, sifat fungsi hukum, dan kemungkinan penafsiranna. Pada produk hukum yang berkarakter responsif, proses pembuatannya bersifat partisipatif, yakni mengundang sebanyakbanyaknya partisipasi masyarakat melalui kelompok-kelompok sosial dan individu didalam masyarakat, sedangkan proses pembuatan produk hukum yang berkarakter ortodoks bersifat sentralistik dalam arti lebih didominasi oleh lembaga negara terutama pemegang kekuasaan eksekutif. $^{3}$

Sementara itu, dilihat dari fungsinya maka hukum yang berkarakter responsif bersifat aspiratif. Artinya memuat materimateri yang secara umum sesuai dengan aspirasi atau kehendak masyarakat yang dilayani. Sehingga produk hukum itu dapat dipandang sebagai kristalisasi dari kehendak masyarakat, sedangkan hukum yang berkarakter ortodoks bersifat positivis-instrumentalis. Artinya memuat materi yang lebih merefleksikan visi sosial dan politik pemegang kekuasaan atau memuat materi yang lebih merupakan alat untuk mewujudkan kehendak dan kepentingan program pemerintah. ${ }^{4}$ Jika dilihat dari segi penafsiran maka produk hukum yang berkarakter responsif biasanya memberi sedikit peluang bagi pemerintah untuk membuat penafsiran sendiri melalui berbagai peraturan pelaksanaan dan peluang yang sempit

Pasal 4 Undang-Undang Nomor 13 Tahun 2003 tentang Ketenagakerjaan.

Moh. Mahfud MD., Politik Hukum di Indonesia, LP3ES, Jakarta, 2001, hlm. 26.

Ibid.

Ibid. 
itupun hanya berlaku untuk hal-hal yang betul-betul bersifat teknis, sedangkan produk hukum yang berkarakter ortodoks memberi peluang yang luas kepada pemerintah untuk membuat berbagai interpretasi dengan berbagai peraturan lanjutan yang berdasarkan visi sepihak dari pemerintah dan tidak sekedar masalah teknis. Produk hukum ortodoks biasanya cenderung memuat materi singkat dan pokok-pokok saja untuk kemudian memberi peluang yang luas bagi pemerintah untuk mengatur berdasarkan visi dan kekuatan politiknya. ${ }^{5}$

Berbagai peraturan perundangundangan di bidang ketenagakerjaan yang selama ini berlaku, termasuk sebagian merupakan produkkolonial,menempatkan manusia kerja sebagai benda, sebagai objek maupun sebagai salah satu faktor produksi, menempatkan pekerja pada posisi yang kurang menguntungkan dalam pelayanan penempatan tenaga kerja dan sistem hubungan industrial yang menonjolkan kedudukan dan kepentingan, sehingga dipandang sudah tidak sesuai lagi dengan perkembangan ketenagakerjaan di Indonesia dan kebutuhan masa kini dan tuntutan masa yang akan datang, karena manusia kerja bukan sebagai objek atau sebagai faktor produksi, melainkan sebagai subjek, sebagai pelaku dalam proses produksi maupun sebagai manusia pribadi dengan segala harkat dan martabatnya. ${ }^{6}$

Peran tenaga kerja dalam pembangunan nasional semakin meningkat dengan disertai berbagai tantangan dan risiko yang dihadapinya. Oleh karena itu, kepada tenaga kerja perlu diberikan perlindungan, pemeliharaan dan peningkatan kesejahteraan, sehingga pada gilirannya akan dapat meningkatkan produktivitas nasional. Peran serta tenaga kerja tersebut menuntut peningkatan kualitas sumber daya manusia dalam pelaksanaan pembangunan nasional, baik sebagai pelaku pembangunan maupun sebagai tujuan pembangunan. Pembangunan tenaga kerja berperan meningkatkan produktivitas nasional dan kesejahteraan masyarakat.Oleh karenanya, tenaga kerja harus diberdayakan supaya mereka memiliki nilai lebih dalam arti lebih mampu, lebih terampil dan lebih berkualitas, agar dapat berdaya guna secara optimal dalam pembangunan nasional dan mampu bersaing dalam era global. Kemampuan, keterampilan dan keahlian tenaga kerja perlu terus ditingkatkan melalui perencanan dan program ketenagakerjaan termasuk pelatihan, pemagangan dan pelayanan penempatan tenaga kerja.

Berdasarkan uraian di atas, maka titik pandang terhadap pekerja merupakan penentu paradigma politik hukum ketenagakerjaan, yaitu mencakup pandangan tentang manusia dan kerja, relasi antara manifestasi kerja (tenaga) dengan upah, dan hak dasar pekerja. Agenda politik hukum ketenagakerjaan ini akan dioperasionalkan apabila terdapat suatu kondisi yang mendukungnya, baik

Ibid.

6 Lihat Mochtar Kusumaatmadja dan B. Arief Sidharta, Pengantar Ilmu Hukum (Suatu Pengenalan

Pertama Ruang Lingkup Berlakunya Ilmu Hukum) Bagian I, Alumni, Bandung, 2000, hlm. 80-81. 
secara sistemik maupun kulturnya yang di dalamnya diperlukan suatu tindakan yang aktual, yaitu membangun kekuatan pekerja, hubungan sosial pekerja dengan produksinya, perlindungan pekerja dengan produksinya, dan kesejahteraan spiritual pekerja. Implementasi dari agenda tersebut titik tekannya bukan hanya sekedar instrumen tetapi akses, mendorong kuantitatif mendidik kualitatif, dan membangun sistem. Di samping itu dalam penegakkan hukum ketenagakerjaan meliputi instrumen keberpihakkan kepada kepentingan pekerja dan merintis peradilan pekerja (peradilan hubungan industrial) yang bermuara pada keadilan dengan proses penyelesaian sederhana, cepat dan biaya ringan (justice delayed, justice denied) dengan tetap mengindahkan prinsipprinsip ketertiban, keadilan, kebenaran dan kepastian hukum dalam menegakkan hukum ketenagakerjaan di Indonesia.

\section{B. PEMBAHASAN}

\section{Arah Pembentukan Undang- Undang Ketenagakerjaan}

Pembangunan ketenagakerjaan harus berlandaskan filosofis, yakni Pancasila dan landasan yuridis konstitusional, yakni Undang-Undang Dasar 1945 sebagai hukum dasar serta landasan yuridis operasional, yakni peraturan perundangundangan yang berrkaitan dengan bidang ketenagakerjaan sebagai dasar hukumnya. Di samping itu, yang tidak kalah penting adalah landasan sosiologis, yakni sesuai dengan tata nilai budaya yang berlaku di masyarakat sehingga dapat menampung segala kenyataan hidup masyarakat dewasa ini. Hal tersebut dimaksudkan, bahwa pembangunan ketenagakerjaan dilaksanakan dalam rangka pembangunan manusia Indonesia seutuhnya dan pembangunan masyarakat seluruhnya. Oleh karena itu, pembangunan ketenagakerjaan dilaksanakan untuk mewujudkan manusia dan masyarakat Indonesia yang sejahtera, adil, makmur dan merata, baik materiil maupun spirituil. $^{7}$

$$
\text { Pada dasarnya masalah }
$$

ketenagakerjaan merupakan agenda sosial, politik, dan ekonomi yang cukup krusial di negara-negara modern, sebab masalah ketenagakerjaan sebenarnya tidak hanya hubungan antara para tenaga kerja dengan pengusaha, tetapi secara lebih luas juga mencakup persoalan sistem ekonomi dari sebuah negara dan sekaligus sistem politiknya. Oleh karena itu, ekonomi dan politik suatu negara akan sangat menentukan corak dan warna dari suatu sistem ketenagakerjaan yang diberlakukannya. ${ }^{8}$

Selama ini persoalan ketenagakerjaan sangat ditentukan oleh sistem ekonomi dunia, sehingga mempengaruhi arah kebijakan hukum ketenagakerjaan yang melahirkan tipe hukum ketenagakerjaan seperti yang dikemukakan oleh Tamara Lothion yang membedakan tipe hukum ketenagakerjaan ke dalam tipe kontraktualis dan tipe korporatis.

\footnotetext{
7 Ujang Charda S., Mengenal Hukum Ketenagakerjaan Indonesia : Sejarah, Teori \& Praktiknya di Indonesia, Fakultas Hukum UNSUB, Subang, 2014, hlm. 25.

8 Abdul Jalil, Teologi Buruh, LKIS Yogyakarta, Yogyakarta, 2008, hlm. v-vi.
} 
Tipe korporatis ini di bidang hukum ketenagakerjaan dilakukan melalui praktik kebijakan legislasi dalam bentuk pembentukan peraturan perundangundangan sebagai usaha pemerintah untuk melakukan pembinaan hukum nasional. ${ }^{9}$ Hal ini semakin mendapatkan dasar pembenaran, jika dihubungkan dengan sistem hukum yang dianut Indonesia sejak awal kemerdekaan berdasarkan asas konkordansi (dari hukum Belanda) yang menganut sistem hukum Eropa Kontinental (Civil Law). ${ }^{10}$

Tipe korporatis digunakan, karena model hubungan kerja yang hendak ditumbuhkan adalah harmoni model, yaitu: ${ }^{11}$

a. Para pihak tidak memiliki kebebasan, melainkan dikuasai oleh pemerintah melalui ketentuan-ketentuan hukum yang bersifat represif.

b. Konsensus (kerjasama) diharuskan dengan melarang terjadinya konflik (pemogokan).

c. Diwajibkan menggunakan penyelesaian secara damai dan melarang penggunaan cara-cara paksaan (mogok atau pun out lock).

Sementara itu, dalam tipe hukum ketenagakerjaan yang kontraktualis hubungan kerja lebih didasarkan pada kekuatan tawar menawar (bargaining position) tenaga kerja terhadap pengusaha, pemerintah bukan sebagai pihak yang aktif membuat regulasi ketenagakerjaan, melainkan hanya bertindak memfasilitasi organisasi tenaga kerja dengan menjamin hak berorganisasi, ${ }^{12}$ maka ciri ini menunjuk pada tipe koalisi yang memiliki ciri hubungan kerja harmonis dan hubungan kerja konflik. ${ }^{13}$

Tipe kontraktualis ini merupakan konsep kapitalis yang menghendaki agar negara tidak terlalu ikut mencampuri persoalan pekerja dengan pengusaha, melainkan diserahkan kepada mekanisme pasar dengan sistem flexible worker, tetapi kembali kepada tujuan hukum ketenagakerjaan serta peran pemerintah masih sangat dibutuhkan dan meniadakan campur tangan negara bukan solusi yang benar-benar tepat. ${ }^{14}$ Untuk itu, antara peran pasar dan campur tangan negara maupun antara pembangunan ekonomi dengan pendekatan pasar dan normatif (konstitusional) harus saling melengkapi, dikarenakan menjalankan pembangunan ekonomi dalam kevakuman politik adalah hal yang mustahil, karena: ${ }^{15}$

a. Peran pasar sangat penting dalam rangka perusahaan memaksimalkan keuntungan dan individu serta masyarakat memaksimalkan kesejahteraan, namun peran

\footnotetext{
$9 \quad$ Ujang Charda S., "Reorientasi Reformasi Model Hukum Ketenagakerjaan dalam Kebijakan Pemerintah", Jurnal Ilmu Hukum Syiar Hukum, Vol. XIV No. 1, Fakultas Hukum UNISBA, Bandung, Maret 2012, hlm. 9.

10 Aloysius Uwiyono, "Implikasi Undang-Undang No. 13 Tahun 2003 Terhadap Iklim Investasi", Jurnal Hukum Bisnis, Volume 22 No. 5, Yayasan Pengembangan Hukum Bisnis, Jakarta, 2003, hlm. 43.

11 Agusmidah, Dilematika Hukum Ketenagakerjaan Tinjauan Politik Hukum, Sofmedia, Medan, 2011, hlm. 10.

12 Ibid.

13 Ibid.

14 Ibid.

15 Ibid., hlm. 11-12.
} 
pemerintah penting juga dalam melakukan koreksi terhadap kegagalan pasar.

b. Peran konstitusi dan aturan main dalam pembuatan kebijakan ekonomi sangat penting untuk memastikan kebijakan ekonomi yang baik dalam rangka meningkatkan kesejahteraan masyarakat untuk jangka panjang.

c. Kebijakan ekonomi dalam mengejar pertumbuhan maupun pemerataan hasil sangat berkaitan dengan proses politik yang berlangsung terus menerus. Kebijakan ekonomi tidak berjalan dalam kevakuman politik, karena secara praktis pendekatan normatif atau konstitusional dapat memberikan arahan yang jelas bagi pembangunan ekonomi dengan saling melengkapi.

Negara sebagai badan hukum publik, sebagai korporasi harus mampu memposisikan dirinya sebagai regulator yang bijak melalui sarana pembentukan dan pelaksanaan hukum ketenagakerjaan, karena hukum ketenagakerjaan akan menjadi sarana utama untuk menjalankan kebijakan pemerintah di bidang ketenagakerjaan itu sendiri. Kebijakan ketenagakerjaan (laborpolicy) di Indonesia dapat dilihat dalam UUD 1945 sebagai konstitusi negara dan juga peraturan perundang-undangan yang terkait. Oleh karena itu, peran negara sangat penting dalam pengaturan keberadaan hukum ketenagakerjaan, hal ini disebabkan pihak yang dilibatkan dalam hubungan kerja umumnya berada pada posisi yang tidak seimbang.

0. Kahn Freund menyatakan, bahwa timbulnya hukum ketenagakerjaan dikarenakan adanya ketidaksetaraan posisi tawar yang terdapat dalam hubungan kerja (antara tenaga kerja dengan pengusaha) dengan alasan itu pula dapat dilihat, bahwa tujuan utama hukum ketenagakerjaan adalah agar dapat meniadakan ketimpangan hubungan di antara keduanya yang timbul dalam hubungan kerja, bahkan asas kebebasan berkontrak dalam perjanjian kerja digambarkan oleh H. Sinzheimer tidak lebih dari sebuah kepatuhan secara sukarela terhadap kondisi-kondisi yang telah ditetapkan secara sepihak oleh pengusaha. ${ }^{16}$

Senada dengan hal tersebut, menurut G. Ripert diaturnya masalah kerja dalam hukum sosial tersendiri (dalam hal ini hukum ketenagakerjaan) adalah akibat kenyataan sosial yang dalam kehidupan ekonomis mengalami pergeseran perlindungan kepentingan dalam kontrak/perjanjian kerja yang merupakan kepentingan umum yang tidak dapat lagi diabaikan berdasarkan asas kebebasan individu serta otonomi individu dalam mengadakan kontrak/perjanjian kerja. ${ }^{17}$ Lebih lanjut Ripert menyatakan, bahwa kekuatan politik tenaga kerja sebagai faktor utama yang mendorong hukum ketenagakerjaan menjadi bagian dari hukum publik. ${ }^{18}$ Bergesernya persepsi ini tidak lepas dari pengalaman sejarah

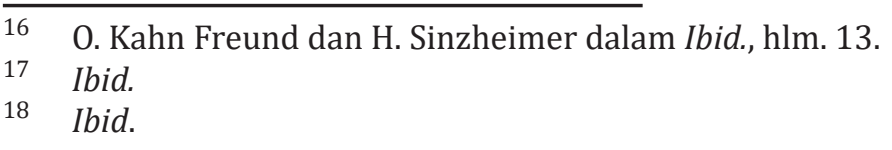


negara, seperti di Perancis yang telah membuktikan gerakan politik pekerja/ buruh mampu membawa ke arah revolusi, begitu juga di Inggris pada abad pertengahan 18 terjadi revolusi industri. ${ }^{19}$

Berdasarkan uraian di atas, tipe hukum ketenagakerjaan Indonesia dalam perlindungan hukum terhadap tenaga kerja adalah tipe hukum ketenagakerjaan yang korporatis. Dalam tipe hukum korporatis ini, perlindungan terhadap tenaga kerja diatur melalui jalan legislasi dalam bentuk peraturan perundangundangan sebagai instrumen kebijakan pemerintah dalam usaha untuk melakukan pembinaan hukum nasional dalam mendayagunakan hukum sebagai sarana merekayasa masyarakat. ${ }^{20}$ Kebijakan legislasi dalam proses penegakan hukum ketenagakerjaan diawali dengan proses penetapan/pembuatan hukum ketenagakerjaan terlebih dahulu oleh badan pembuat undang-undang. Tahap ini dapat disebut sebagai tahap kebijakan legislasi/formulatif. ${ }^{21}$ Dilihat dari keseluruhan proses penegakan hukum ketenagakerjaan, tahap kebijakan legislasi/formulatif ini merupakan tahap yang paling strategis. Oleh karena itu, kesalahan/kelemahan kebijakan legislasi merupakan kesalahan strategis yang dapat menghambat upaya penegakan hukum pada tahap berikutnya, yaitu tahap aplikatif/kebijakan yudikatif dan tahap eksekusi/kebijakan administratif. ${ }^{22}$ Apabila hal ini terjadi, maka reformasi hukum, apalagi supremasi hukum hanya akan tetap sebagai harapan belaka. ${ }^{23}$

Norma dasar memberikan landasan bagi aturan dasar yang merupakan tatanan suatu negara dalam bentuk Undang-Undang Dasar atau konstitusi tertulis, maka aturan dasar tersebut pada gilirannya merupakan landasan hukum perundang-undangan (gesetzesrecht) yang berlaku dalam negara. ${ }^{24}$ Oleh karena itu, UUD 1945 sebagai landasan konstitusional merupakan arah politik hukum ketenagakerjaan nasional yang dimuat pada Alinea Keempat Pembukaan UUD 1945, yaitu: “...melindungi segenap bangsa Indonesia dan seluruh tumpah darah Indonesia, memajukan kesejahteraan umum..." yang berkorelasi dengan Pasal 1 ayat (3) UUD 1945, bahwa: "Negara Indonesia adalah negara hukum".

Pasal 1 ayat (3) UUD 1945 tersebut dapat dikorelasikan dengan pasal-pasal yang mengatur tentang ketenagakerjaan, seperti Pasal 27 ayat (2) yang berbunyi: "Tiap-tiap warga negara berhak atas pekerjaan dan penghidupan yang layak bagi kemanusiaan", Pasal 28D ayat (2) berbunyi: "Setiap orang berhak untuk bekerja serta mendapat imbalan dan perlakuan yang adil dan layak dalam

\footnotetext{
19 Marsen Sinaga, Pengadilan Perburuhan di Indonesia (Tinjauan Hukum Kritis atas Undang-Undang PPHI), Semarak Cemerlang Nusa (SCN), Yogyakarta, 2006, hlm. 11.

20 Soetandyo Wignjosoebroto, Dari Hukum Kolonial ke Hukum Nasional : Dinamika Sosial Politik dalam Perkembangan Hukum di Indonesia, RajaGrafindo Persada, Jakarta, 1994, hlm. 231.

21 Dwidja Priyatno, Kebijakan Legislasi tentang Sistem Pertanggungjawaban Pidana Korporasi di Indonesia, Utomo, Bandung, 2004, hlm. 8.

22 Ibid.

23 Ibid.

24 Ni'matul Huda, Negara Hukum, Demokrasi \& Judicial Review, UII Press, Yogyakarta, 2005, hlm. 52.
} 
hubungan kerja". Kemudian dipertegas oleh Pasal 28I ayat (2) UUD 1945 yang menyatakan, sebagai berikut:

"Setiap orang berhak bebas dari perlakuan yang bersifat diskriminatif atas dasar apapun dan berhak mendapatkan perlindungan terhadap perlakuan yang bersifat diskriminatif itu".

Menurut Ismail Sunny, ketentuan Pasal 27 ayat (2) UUD 1945 di atas merupakan a paper constitutional atau $a$ semantic constitutional dengan mengakui hak warga negaranya untuk mendapatkan pekerjaan, ${ }^{25}$ maka sebenarnya Indonesia telah bertekad dan memutuskan untuk melenyapkan pengangguran, sehingga negara berani memasukan pasal tersebut dalam konstitusinya. ${ }^{26}$ Oleh karena itu, Pasal 27 ayat (2) UUD 1945 harus ditafsirkan sebagai berikut: ${ }^{27}$

“...bahwa pemerintah berkewajiban untuk memberantas pengangguran dan harus mengusahakan supaya setiap warga negara bisa mendapat pekerjaan dengan nafkah yang layak untuk hidup, bukan hanya asal bekerja saja sekalipun dengan penindasan atau eksploitasi, melainkan harus layak untuk penghidupan".

Secara fundamental hukum ketenagakerjaan Indonesia bukan hanya harus berlandaskan pada Pasal 27 ayat (2), Pasal 28D ayat (2), Pasal 28I ayat
(2) UUD 1945, tetapi berlandaskan pula pada Pasal 33 ayat (1) UUD 1945 yang mengatur tentang dasar perekonomian negara Indonesia yang secara historis pernah dikemukakan oleh Moch. Hatta yang memberikan konseptual Pasal 33 dengan istilah demokrasi ekonomi dengan mengedepankan kemakmuran rakyat dan bukan kemakmuran orang perseorangan, sehingga perekonomian Indonesia disusun sebagai usaha bersama berdasarkan asas kekeluargaan. ${ }^{28}$

Sementara itu, di dalam UndangUndang Nomor 13 Tahun 2003 mengatur lebih lanjut mengenai arah kebijakan pemerintah dalam pembangunan hukum ketenagakerjaan adalah dengan mengikutsertakan unsur dunia usaha dan masyarakat, melakukan pembinaan terhadap segala kegiatan yang berhubungan dengan ketenagakerjaan yang pelaksanaannya dilakukan secara terpadu dan terkoordinasi. Apabila mengkaji hakikat dari Undang-Undang Nomor 13 Tahun 2003 yang menyandang nama besar sebagai Undang-Undang Ketenagakerjaan adalah suatu undangundang yang memberikan perlindungan pada tenaga kerja bukan pada pekerja. Hal ini dapat diketahui pada dasar filosofis terbentuknya Undang-Undang Nomor 13 Tahun 2003 yang dapat dilihat dari konsiderans menimbang huruf $a$, huruf $b$, dan huruf c sebagai berikut:

"a. bahwa pembangunan nasional dilaksanakan dalam rangka

25 Ismail Sunny, Hak Asasi Manusia, Yarsif Watampone, Jakarta, 2004, hlm. 8-9.

26 Ibid.

27 R. Wiyono, Garis Besar Pembahasan dan Komentar UUD 1945, Alumni, Bandung, 1976, hlm. 194-195.

28 Muh. Hatta dalam Sri Bintang Pamungkas, Pokok-pokok Pikiran tentang Demokrasi Ekonomi dan Pembangunan, Yayasan Daulat Rakyat, Jakarta, 1996, hlm. 1. 
pembangunan manusia Indonesia seutuhnya dan pembangunan masyarakat Indonesia seluruhnya untuk mewujudkan masyarakat yang sejahtera, adil, makmur, yang merata, baik materiil maupun spiritual berdasarkan Pancasila dan UndangUndang Dasar Negara Republik Indonesia Tahun 1945;

b. bahwa dalam pelaksanaan pembangunan nasional, tenaga kerja mempunyai peranan dan kedudukan yang sangat penting sebagai pelaku dan tujuan pembangunan;

c. bahwa sesuai dengan peranan dan kedudukan tenaga kerja, diperlukan pembangunan ketenagakerjaan untuk meningkatkan kualitas tenaga kerja dan peran sertanya dalam pembangunan serta peningkatan perlindungan tenaga kerja dan keluarganya sesuai dengan harkat dan martabat kemanusiaan".

Berdasarkan konsiderans huruf a, huruf b, dan huruf c Undang-Undang Nomor 13 Tahun 2003, dapat diketahui bahwa pembentuk undang-undang menghendaki dibuatnya suatu aturan hukum yang memberikan perlindungan hukum kepada tenaga kerja, mengingat peranan dan kedudukannya yang sangat penting sebagai pelaku dan tujuan pembangunan.

Dasar filosofis tersebut dijelaskan lebih lanjut mengenai pembangunan ketenagakerjaan dalam Penjelasan Umum Undang-Undang Nomor 13 Tahun 2003, sebagai berikut:

“...sebagai bagian integral dari pembangunan nasional berdasarkan
Pancasila dan Undang-Undang Dasar Negara Republik Indonesia Tahun 1945, dilaksanakan dalam rangka pembangunan manusia Indonesia seutuhnya dan pembangunan masyarakat Indonesia seluruhnya untuk meningkatkan harkat, martabat, dan harga diri tenaga kerja, serta mewujudkan masyarakat sejahtera, adil, makmur, dan merata, baik materiil maupun spiritual. Pembangunan ketenagakerjaan harus diatur sedemikian rupa, sehingga terpenuhi hak-hak dan perlindungan yang mendasar bagi tenaga kerja dan pekerja/buruh serta pada saat yang bersamaan dapat mewujudkan kondisi yang kondusif bagi pengembangan dunia usaha".

Perlindungan hukum bagi tenaga kerja merupakan perwujudan dari usaha untuk memajukan kesejateraan umum, tetapi dasar filosofi yang ditetapkan oleh pembuat Undang-Undang Nomor 13 Tahun 2003 ini, ternyata tidak konsisten. Hal ini tampak dalam rumusan konsiderans menimbang huruf d UndangUndang Nomor 13 Tahun 2003 sebagai berikut:

"Perlindungan terhadap tenaga kerja dimaksudkan untuk menjamin hak-hak dasar pekerja/buruh dan menjamin kesamaan kesempatan kerja serta perlakuan tanpa diskriminasi atas dasar apapun untuk mewujudkan kesejahteraan pekerja/ buruh dan keluarganya dengan tetap memperhatikan perkembangan kemajuan dunia usaha". 
Konsiderans menimbang huruf d Undang-Undang Nomor 13 Tahun 2003 tersebut, membatasi pengertian tenaga kerja hanya mencakup pekerja saja bukan tenaga kerja, hal ini menunjukkan adanya pertentangan norma antara konsiderans menimbang huruf $a$, huruf $b$, dan huruf c dengan konsiderans huruf d UndangUndang Nomor 13 Tahun 2003. Lebih lanjut, dasar filosofi yang ada pada konsiderans menimbang huruf a, huruf b, dan huruf c tersebut tidak diterapkan dalam pasal-pasal Undang-Undang Nomor 13 Tahun 2003, khususnya hanya membatasi pekerja yang bekerja pada pengusaha saja, bukan pekerja yang bekerja pada pemberi kerja. Ini berarti substansi Undang-Undang Nomor 13 Tahun 2003 hanya menitikberatkan pada pengaturan hubungan kerja di sektor formal.

Sementara itu, pembangunan hukum ketenagakerjaan, sasarannya diarahkan kepada pembinaan tenaga kerja untuk: ${ }^{29}$

a. Mewujudkan perencanaan tenaga kerja dan informasi ketenagakerjaan.

b. Mendayagunakan tenaga kerja secara optimum serta menyediakan tenaga kerja yang sesuai dengan pembangunan nasional.

c. Mewujudkan terselenggaranya pelatihan kerja yang berkesinambungan guna meningkatkan kemampuan, keahlian, dan produktivitas tenaga kerja.

d. Menyediakan informasi pasar kerja, pelayanan penempatan tenaga kerja yang sesuai dengan bakat, minat, dan kemampuan tenaga kerja pada pekerjaan yang tepat.

e. Mewujudkan tenaga kerja mandiri.

f. Menciptakan hubungan yang harmonis dan terpadu antara pelaku proses produksi barang dan jasa dalam mewujudkan hubungan industrial Pancasila.

g. Mewujudkan kondisi yang harmonis dan dinamis dalam hubungan kerja yang meliputi terjaminnya hak pengusaha dan pekerja.

h. Memberikan perlindungan tenaga kerja yang meliputi keselamatan dan kesehatan kerja, pengupahan, jamsostek, serta syarat kerja.

Dalam pembangunan ketenagakerjaan, pemerintah menetapkan kebijakan dan menyusun perencanaan tenaga kerja. Perencanaan tanaga kerja meliputi: ${ }^{30}$

a. Perencanaan tenaga kerja makro, maksudnya bahwa proses penyusunan rencana ketenagakerjaan secara sistematis yang memuat pendayagunaan tenaga kerja secara optimal dan produktif guna mendukung pertumbuhan ekonomi atau sosial, baik secara nasional, daerah, maupun sektoral, sehingga dapat membuka kesempatan kerja seluas-luasnya, meningkatkan produktivitas kerja dan meningkatkan kesejahteraan pekerja.

b. Perencanaan tenaga kerja mikro, maksudnya bahwa proses penyusunan rencana ketenagakerjaan secara sistematis dalam suatu instansi, baik instansi pemerintah maupun swasta

29 Ujang Charda S., Mengenal ... Op. Cit., hlm. 26-27.

$30 \quad$ Pasal 7 ayat (2) dan penjelasannya Undang-Undang Nomor 13 Tahun 2003. 
dalam rangka pendayagunaan tenaga kerja secara optimal dan produktif untuk mendukung pencapaian kinerja yang tinggi pada instansi atau perusahaan yang bersangkutan.

Di dalam menyusun kebijakan, strategi, dan pelaksanaan program pembangunan yang berkesinambungan, pemerintah harus berpedoman kepada perencanaan tenaga kerja yang disusun atas dasar informasi ketenagakerjaan yang antara lain meliputi: ${ }^{31}$

a. Penduduk dan tenaga kerja.

b. Kesempatan kerja.

c. Pelatihan kerja termasuk kompensasi kerja.

d. Produktivitas tenaga kerja.

e. Hubungan industrial.

f. Kondisi lingkungan kerja.

g. Pengupahan dan kesejahteraan tenaga kerja.

h. Jaminan sosial tenaga kerja.

\section{Karakteristik Undang-Undang Kete-} nagakerjaan dalam Perlindungan Hukum Terhadap Tenaga Kerja

Lahirnya Undang-Undang Nomor 13 Tahun 2003 tentang ketenagakerjaan sebagai jawaban atas permasalahan yang mengatur di bidang ketenagakerjaan dan mempunyai tujuan yang luhur bagi tenaga kerja Indonesia. Hal tersebut dapat dilihat di dalam Pasal 4 Undang-Undang Nomor 13 Tahun 2003 yang menyatakan sebagai berikut:

"Pembangunan ketenagakerjaan bertujuan: a. memberdayakan dan mendayagunakan tenaga kerja secara optimal dan manusiawi;

b. mewujudkan pemerataan kesempatan kerja dan penyediaan tenaga kerja yang sesuai dengan kebutuhan pembangunan nasional dan daerah;

c. memberikan perlindungan kepada tenaga kerja dalam mewujudkan kesejahteraan; dan

d. meningkatkan kesejahteraan tenaga kerja dan keluarganya".

Tujuan Undang-Undang Nomor 13 Tahun 2003 yang merupakan argumen politik para pembentuk undang-undang yang dimuat dalam Pasal 4 UndangUndang Nomor 13 Tahun 2003 tersebut di atas adalah sangat jelas dan mempunyai tujuan yang baik. Studi ini berangkat dari asumsi dasar, bahwa hukum merupakan produk politik dan juga dalam studi ini karakter produk hukum yang ingin diketahui difokuskan pada karakter hukum responsif, seperti yang dikemukakan oleh Nonet dan Selznick, dan karakter hukum ortodoks, seperti yang dikemukakan Marryman. ${ }^{32}$ Untuk mengetahui apakah UUK berkarakter hukum responsif atau berkarakter hukum ortodoks, maka dalam studi ini digunakan indikator-indikator untuk menentukan karakter UUK tersebut. Adapun indikator-indikatornya adalah sebagai berikut: ${ }^{33}$

a. Proses pembuatan hukum

Pada produk hukum yang berkarakter responsif, proses

\footnotetext{
$31 \quad$ Lihat Pasal 8 Undang-Undang Nomor 13 Tahun 2003.

32 http://partaiburuhkarawang.blogspot.com/2011/03/karakter-undang-undang-nomor-13-tahun.html, akses tanggal 21 Pebruari 2013, jam 12 : 45 WIB.

33 Ibid.
} 
pembuatannya bersifat partisipatif, yakni mengundang sebanyakbanyaknya partisipasi masyarakat melalui kelompok-kelompok sosial dan individu didalam masyarakat, sedangkan proses pembuatan produk hukum yang berkarakter ortodoks bersifat sentralistik dalam arti lebih didominasi oleh lembaga negara terutama pemegang kekuasaan eksekutif. ${ }^{34}$

Terbentuknya suatu peraturan perundang-undangan, adalah melalui tahapan-tahapan yang telah ditentukan oleh suatu peraturan perundang-undang. Tahapantahapan tersebut antara lain, tahap perencanaan, tahap persiapan, tahap pembahasan rancangan undangundang, tahap pengesahan dan tahap pengundangan. Tahapan-tahapan pembentukan peraturan perundangundangan sepenuhnya dilaksanakan oleh lembaga yang berwenang untuk itu. Dalam hal ini lembaga DPR yang khusus menangani bidang legislasi, dan Pemerintah (Presiden) yang dikoordinasikan oleh menteri yang tugas dan tanggung jawabnya meliputi bidang peraturan perundangundangan. ${ }^{35}$ Khusus untuk tahap persiapan dan tahap pembahasan rancangan undang-undang, masyarakat dapat berpartisipasi dan bahkan berhak untuk memberikan masukan baik secara lisan maupun tertulis. ${ }^{36}$
Dalam hal ini, peran masyarakat sangat diperlukan untuk memberikan aspirasinya, baik secara individu maupun kelompok, agar suatu peraturan perundang-undangan yang nantinya telah disahkan dan diundangkan, akan berkarakter responsif atau sesuai dengan aspirasi masyarakat. Karena hukum yang baik adalah hukum yang sesuai dengan hukum yang hidup di dalam masyarakat.

Pada saat Undang-Undang Nomor 13 Tahun 2003 masih berbentuk draft naskah dalam tahap pembahasan di DPR, serikat-serikat buruh bergabung dengan kelompok pemerhati perburuhan aktif menyampaikan aspirasinya. Selama pertengahan tahun 2000 sampai tahun 2003 mereka terus melakukan penolakan terhadap draft Undang-Undang Nomor 13 Tahun 2003 tersebut. Penolakan utamanya ditujukan pada isu-isu yang berkaitan dengan longgarnya aturan pemutusan hubungan kerja, pengetatan hak mogok, dan aturan legalisasi sistem kerja kontrak dan outsourcing. ${ }^{37}$ Berbagai serikat buruh memberikan aspirasinya dengan berbagai macam cara, mulai dari menggalang aksi bersama sampai dengan melakukan lobby politik ke lembaga pemerintah dan DPR-RI. Tapi sayangnya, pemerintah dan DPR mengabaikan aspirasi kaum buruh yang menolak

34 Moh. Mahfud MD., Politik ... Op. Cit., hlm. 26.

35 http://partaiburuhkarawang.blogspot.com/.... Loc. Cit.

36 Lihat Pasal 53 Undang-Undang Nomor 10 Tahun 2004 tentang Pembentukan Peraturan Perundangundangan.

37 http://partaiburuhkarawang.blogspot.com/.... Loc. Cit. 
draft Undang-Undang Nomor 13 Tahun 2003 tersebut, dan berkeras untuk mengesahkan Undang-Undang Nomor 13 Tahun 2003 pada bulan Maret 2003 lalu. $^{38}$

Karena dalam pembentukannya tidak bersifat partisipatif dan aspiratif, maka kaum buruh tetap melakukan penolakan walaupun Undang-Undang Nomor 13 Tahun 2003 tersebut sudah disahkan dan diundangkan. Hal ini dapat kita lihat dengan bergabungnya sebanyak 33 federasi serikat buruh nasional, sekaligus bersama-sama mengajukan gugatan uji materiil (judicial review) ke Mahkamah Konstitusi. Ke-33 federasi serikat buruh nasional tersebut mendalilkan pemberlakuan sistem kerja outsourcing sebagai legalisasi negara terhadap praktik perbudakan modern. ${ }^{39}$ Para pemohon dalam judicial review menyodorkan Pasal 64 sampai Pasal 66 UndangUndang Nomor 13 Tahun 2003 sebagai bentuk pelanggaran atas hak konstitusional buruh sebagai warga negara Indonesia atas kepastian kerja yang dijamin dalam UUD 1945. Namun sayang sekali, putusan Mahkamah Konstitusi Republik Indonesia Nomor 012/PPU-I/2003, tanggal 28 Oktober 2004, menolak dalil tersebut. Dari uraian di atas dapat diringkas, bahwa dalam proses pembentukan Undang-Undang Nomor 13 Tahun 2004, tidak bersifat partisipatif, yakni tidak mengundang sebanyakbanyaknya partisipasi masyarakat melalui kelompok-kelompok sosial dan individu di masyarakat khususnya serikat buruh yang membawa aspirasi kaum buruh secara umum. ${ }^{40}$

b. Sifat fungsi hukum

Dilihat dari fungsinya maka hukum yang berkarakter responsif bersifat aspiratif. Artinya memuat materi-materi yang secara umum sesuai dengan aspirasi atau kehendak masyarakat yang dilayani. Sehingga produk hukum itu dapat dipandang sebagai kristalisasi dari kehendak masyarakat, sedangkan hukum yang berkarakter ortodoks bersifat positivis-instrumentalis. Artinya memuat materi yang lebih merefleksikan visi sosial dan politik pemegang kekuasaan atau memuat materi yang lebih merupakan alat untuk mewujudkan kehendak dan kepentingan program pemerintah. ${ }^{41}$

Dari sudut pandang kaum buruh, materi muatan Undang-Undang Ketenagakerjaan tidak aspiratif, karena tidak sesuai dengan kehendak buruh yang dilayani. Dapat terlihat dari alasan-alasan kaum buruh menolak undang undang tersebut. Sebaliknya, materi muatan UndangUndang Ketenagakerjaan dipandang oleh kaum buruh sebagai peraturan yang merefleksikan visi sosial dan politik pemegang kekuasaan, sehingga peraturan tersebut lebih merupakan 
alat untuk mewujudkan kehendak dan kepentingan program pemerintah. Hal tersebut dapat dirasakan dari lahirnya Undang-Undang Nomor 13 Tahun 2003 ini. Lahirnya undang-undang ini ada berbagai macam pemaksaan yang dilakukan oleh badan-badan donor internasional terhadap pemerintah Indonesia, sebagai konsekusensi perjanjian yang telah dibuat antara pemerintah Indonesia dengan lembaga internasional itu. ${ }^{42}$ Bentuk-bentuk pemaksaan ini dapat ditemui melalui penghapusan tarif (penghapusan pajak import, dan kuota eksport). Indonesia sebagai negara berkembang adalah salah satu negara yang terkena dampak akibat pemaksaan lembaga-lembaga donor kapitalis internasional tersebut, yaitu sejak ditandatanganinya LoI (Letter of Intens) antara pemerintah Indonesia dengan $I M F$, yang salah satu pointnya adalah bahwa pemerintah Indonesia harus melakukan reformasi terhadap hukum perburuhan yang dipandang terlalu memberikan perlindungan (protection) terhadap buruhnya dan sudah tidak sesuai dengan kebutuhan dan perkembangan jaman, yang akhirnya lahir 3 (tiga) paket undang undang yaitu Undang Undang Nomor 21 Tahun 2000 tentang Serikat Pekerja/Serikat Buruh, Undang Undang Nomor 13 Tahun 2003 tentang Ketenagakerjaan dan Undang Undang Nomor 2 Tahun 2004 tentang
Penyelesaian Perselisihan Hubungan Industrial. ${ }^{43}$ Dari uraian-uraian di atas, kaum buruh berpandangan, bahwa sifat fungsi Undang-Undang Ketenagakerjaan tidak aspiratif, sebab sifat fungsinya secara umum bertentangan dengan kehendakkehendak buruh. ${ }^{44}$

c. Kemungkinan penafsirannya

Dilihat dari segi penafsiran, maka produk hukum yang berkarakter responsif biasanya memberi sedikit peluang bagi pemerintah untuk membuat penafsiran sendiri melalui berbagai peraturan pelaksanaan dan peluang yang sempit itupun hanya berlaku untuk hal-hal yang betulbetul bersifat teknis, sedangkan produk hukum yang berkarakter ortodoks memberi peluang yang luas kepada pemerintah untuk membuat berbagai interpretasi dengan berbagai peraturan lanjutan yang berdasarkan visi sepihak dari pemerintah dan tidak sekedar masalah teknis. Produk hukum ortodoks biasanya cenderung memuat materi singkat dan pokokpokok saja untuk kemudian memberi peluang yang luas bagi pemerintah untuk mengatur berdasarkan visi dan kekuatan politiknya. ${ }^{45}$

Isi dari Undang Undang Nomor 13 Tahun 2003 tentang Ketenagakerjaan terdiri dari 17 bab, 193 pasal. Dari 193 pasal hanya terdapat 77 pasal yang ada penjelasannyaatauterdapat116 pasalyang dinyatakan cukup jelas oleh pembentuk 
undang-undang. Sehingga, hanya kurang lebih 40\% saja dari keseluruhan pasal yang dijelaskan atau sebanyak $60 \%$ pasal yang tidak ada penjelasannya atau dianggap cukup jelas. Sebanyak 60\% pasal yang dianggap cukup jelas menurut argumen politik para pembentuk undang-undang tersebut, adalah suatu jumlah yang cukup besar menurut pandangan kaum buruh, karena sebanyak 116 pasal tersebut dapat terjadi multi tafsir, sehingga dapat terjadi penafsiran yang berbeda-beda baik oleh pemerintah, kaum buruh maupun pengusaha atau pihak lainnya. ${ }^{46}$

Telah dikemukakan sebelumnya, bahwa jika dilihat dari segi penafsiran, maka suatu produk hukum yang berkarakter responsif biasanya memberi sedikit peluang bagi pemerintah untuk membuat penafsiran sendiri melalui berbagai peraturan pelaksanaan dan peluang yang sempit itupun hanya berlaku untuk hal-hal yang betul-betul bersifat teknis, sedangkan produk hukum yang berkarakter ortodoks memberi peluang yang luas kepada pemerintah untuk membuat berbagai interpretasi dengan berbagai peraturan lanjutan yang berdasarkan visi sepihak dari pemerintah dan tidak sekedar masalah teknis. Produk hukum ortodoks biasanya cenderung memuat materi singkat dan pokokpokok saja untuk kemudian memberi peluang yang luas bagi pemerintah untuk mengatur berdasarkan visi dan kekuatan politiknya. $^{47}$

Undang Undang Nomor 13 Tahun 2003, ternyata memberikan peluang yang besar kepada pemerintah untuk membuat berbagai interpretasi dengan berbagai peraturan lanjutan yang berdasarkan visi sepihak dari pemerintah dan tidak sekedar masalah teknis. Hal tersebut dapat dilihat dengan banyaknya peraturan pelaksanaan dari Undang-Undang Ketenagakerjaan dan peraturan-peraturan non-pelaksanaannya, seperti: Kepmenakertrans Nomor: Kep.21/ MEN/III/2004, tanggal 1 Maret 2004 tentang Penggunaan Tenaga Kerja Asing, Kepmenakertrans Nomor: Kep.67/Men/ IV/2004 tanggal 26 April 2004 tentang Pelaksanaan Program Jaminan Sosial Tenaga Kerja Bagi Tenaga Kerja Asing, Kepmenakertrans Nomor: Kep.68/MEN/ IV/2004, tanggal 28 April 2004 tentang Pencegahan dan Penanggulangan HIV/ AIDS di Tempat Kerja, Kepmenakertrans Nomor 69/MEN/ IV/2004, tanggal 4 Mei 2004 tentang Perubahan Lampiran Keputusan Kepmenakertrans Nomor: Kep.227/MEN/2003 tentang Tata Cara Penetapan Standar Kompetensi Kerja Nasional, dan masih banyak lagi yang lainnya. Banyaknya peraturan pelaksanaan dari Undang-Undang Nomor 13 Tahun 2003 tentang Ketenagakerjaan serta peraturan non pelaksanaan undang undang tersebut membuktikan, bahwa dengan lahirnya Undang-Undang Ketenagakerjaan memberi peluang yang luas kepada pemerintah untuk membuat berbagai interpretasi dengan berbagai peraturan lanjutan yang berdasarkan visi sepihak dari pemerintah dan tidak sekedar masalah teknis. 
Dengan menggunakan tiga indikator, yaitu proses pembuatan, sifat fungsi produk hukum, dan kemungkinan penafsiran, maka dapat diketahui apakah suatu produk hukum berkarakter responsif ataukah ortodoks. Indikator pertama, yaitu proses pembuatan. Di atas telah dikemukakan, bahwa proses pembuatan Undang- Undang Nomor 13 Tahun 2003 tidak bersifat partisipatif, yakni tidak mengundang sebanyakbanyaknya partisipasi masyarakat melalui kelompok-kelompok sosial dan individu di masyarakat khususnya serikat buruh yang membawa aspirasi kaum buruh secara umum. Indikator kedua yaitu sifat fungsi produk hukum, bahwa sifat fungsi dari Undang Undang Nomor 13 Tahun 2003 adalah tidak aspiratif, sebab sifat fungsinya secara umum bertentangan dengan dengan kehendak-kehendak atau aspirasi kaum buruh. Sementara itu, indikator ketiga, yaitu kemungkinan penafsiran, bahwa penjelasan dari undangundang tersebut, hanya menjelaskan sebanyak $40 \%$ saja dari jumlah pasal yang ada. Artinya sebanyak 60\% pasal yang dianggap telah jelas membuka peluang terjadinya multi tafsir dari berbagai pihak, dan juga dengan banyaknya peraturan pelaksanaan dari Undang Undang Nomor 13 Tahun 2003 tentang Ketenagakerjaan serta peraturan non-pelaksanaan undang-undang tersebut, membuktikan, bahwa dengan lahirnya Undang Undang Ketenagakerjaan memberi peluang yang luas kepada pemerintah untuk membuat berbagai interpretasi dengan berbagai peraturan lanjutan yang berdasarkan visi sepihak dari pemerintah dan tidak sekedar masalah teknis. Dengan demikian, dapat disimpulkan bahwa Undang-Undang Nomor 13 Tahun 2003 adalah merupakan suatu produk hukum yang berkarakter konservatif/ortodoks. ${ }^{48}$

Berdasarkan uraian di atas, bahwa dalam pembangunan ketenagakerjaan mempunyai banyak dimensi dan keterkaitannya tidak hanya dengan kepentingan tenaga kerja sebelum, selama dan sesudah masa kerja, tetapi juga dengan kepentingan pengusaha, pemerintah, dan masyarakat. Oleh karena itu, diperlukan pengaturan yang menyeluruh dan komprehensif, antara lain mencakup perencanaan tenaga kerja, pembangunan sumber daya manusia, perluasan kesempatan kerja, pelayanan penempatan tenaga kerja, pembinaan hubungan industrial, peningkatan perlindungan tenaga kerja, serta peningkatan produktivitas kerja dan daya saing tenaga kerja di dalam dan di luar negeri. ${ }^{49}$

Dikeluarkannya berbagai peraturan perundang-undangan di bidang ketenagakerjaan yang selama ini berlaku, termasuk sebagian merupakan produk kolonial, menempatkan manusia kerja sebagai benda, sebagai objek maupun sebagai salah satu faktor produksi, menempatkan pekerja pada posisi yang kurang menguntungkan dalam pelayanan penempatan tenaga kerja dan sistem hubungan industrial yang menonjolkan kedudukan dan kepentingan, sehingga dipandang sudah tidak sesuai lagi

\footnotetext{
$48 \quad$ Ibid.

49 Ujang Charda S., Mengenal ... Op. Cit., hlm. 3.
} 
dengan perkembangan ketenagakerjaan di Indonesia dan kebutuhan masa kini dan tuntutan masa yang akan datang, karena manusia kerja bukan sebagai objek atau sebagai faktor produksi, melainkan sebagai subjek, sebagai pelaku dalam proses produksi maupun sebagai manusia pribadi dengan segala harkat dan martabatnya. ${ }^{50}$

Peran tenaga kerja dalam pembangunan nasional semakin meningkat dengan disertai berbagai tantangan dan risiko yang dihadapinya. Oleh karena itu, kepada tenaga kerja perlu diberikan perlindungan, pemeliharaan dan peningkatan kesejahteraan, sehingga pada gilirannya akan dapat meningkatkan produktivitas nasional. Peran serta tenaga kerja tersebut menuntut peningkatan kualitas sumber daya manusia dalam pelaksanaan pembangunan nasional, baik sebagai pelaku pembangunan maupun sebagai tujuan pembangunan. Pembangunan tenaga kerja berperan meningkatkan produktivitas nasional dan kesejahteraan masyarakat.Oleh karenanya, tenaga kerja harus diberdayakan supaya mereka memiliki nilai lebih dalam arti lebih mampu, lebih terampil dan lebih berkualitas, agar dapat berdaya guna secara optimal dalam pembangunan nasional dan mampu bersaing dalam era global. Kemampuan, keterampilan dan keahlian tenaga kerja perlu terus ditingkatkan melalui perencanan dan program ketenagakerjaan termasuk pelatihan, pemagangan dan pelayanan penempatan tenaga kerja.

Atas dasar tersebut, politik hukum ketenagakerjaan nasional Indonesia dalam perlindungan tenaga kerja harus ditujukan kepada kebahagiaan tenaga kerja Indonesia dengan berdasarkan pada falsafah Pancasila yang kemudian dijelmakan dalam sebuah aturan undangundang untuk dijadikan dasar hukum bagi pelaksanaan politik hukum tersebut. Oleh karena itu, konsekuensinya harus dapat melenyapkan pola pemikiran kolonial yang menempatkan orang sebagai objek hukum, sehingga tidak akan terulang kembali di masa-masa kemerdekaan ini.

Dalam rangka menata politik hukum ketenagakerjaan, pemerintah menetapkan sejumlah kebijakan pembangunan ketenagakerjaan dalam perlindungan tenaga kerja dengan menyusun perencanaan tenaga kerja melalui perencanaan makro dan mikro. ${ }^{51}$ Dalam menyusun kebijakan, strategi, dan pelaksanaan program perlindungan tenaga kerja melalui hukum ketenagakerjaan dilakukan dengan berkesinambungan, dan pemerintah harus berpedoman pada

50 Mochtar Kusumaatmadja dan B. Arief Sidharta, Loc. Cit.

51 Penjelasan Pasal 7 ayat (2) hurup a Undang-Undang Nomor 13 Tahun 2003 tentang Ketenagakerjaan mengemukakan, bahwa perencanaan makro adalah proses penyusunan rencana ketenagakerjaan secara sistematis yang memuat pendayagunaan tenaga kerja secara optimal dan produktif guna mendukung pertumbuhan ekonomi atau sosial, baik secara nasional, daerah maupun sektoral sehingga dapat membuka kesempatan kerja seluas-luasnya, meningkatkan produktivitas kerja dan meningkatkan kesejahteraan pekerja. Sementara itu, penjelasan Pasal 7 ayat (2) hurup b Undang-Undang Nomor 13 Tahun 2003 tentang Ketenagakerjaan mengemukakan, bahwa perencanaan mikro adalah proses penyusunan rencana ketenagakerjaan secara sistematis dalam suatu instansi, baik instansi pemerintah maupun swasta dalam rangka meningkatkan pendayagunaan tenaga kerja secara optimal dan produktif untuk mendukung pencapaian kinerja yang tinggi pada instansi atau perusahaan yang bersangkutan. 
perencanaan tenaga kerja yang ditetapkan oleh pemerintah. Pendekatan perencanaan tenaga kerja dapat dilakukan secara nasional, daerah, dan sektoral yang disusun atas dasar informasi ketenagakerjaan yang antara lain meliputi: penduduk dan tenaga kerja, kesempatan kerja, pelatihan kerja termasuk kompetensi kerja, produktivitas tenaga kerja, hubungan industrial, kondisi lingkungan kerja, pengupahan dan kesejahteraan tenaga kerja, dan jaminan sosial tenaga kerja. $^{52}$ Setiap kebijakan pemerintah dalam perlindungan tenaga kerja harus dilihat dalam rangka meningkatkan kesejahteraan warga negaranya, walaupun hal ini ternyata bukan tugas ringan bagi negara manapun juga, namun menjadi kewajiban yang harus diwujudkan dalam rangka mencapai tujuan negara. ${ }^{53}$ Oleh karena itu, hak untuk bekerja (right to work) bagi setiap warga negara merupakan tanggung jawab pemerintah/negara yang harus berupaya semaksimal mungkin.

Pengaturan masalah ketenagakerjaan dalam Undang-Undang Nomor 13 Tahun 2003 tentang Ketenagakerjaan yang menitikberatkan pada aspek hubungan kerja, berarti tidak sejalan dengan ruang lingkup hukum ketenagakerjaan yang mencakup segala hal yang berhubungan dengan tenaga kerja sebelum, selama, dan sesudah masa kerja. Oleh karena itu, terhadap Undang-Undang Nomor 13 Tahun 2003 tentang Ketenagakerjaan diusulkan harus segera direvisi dan memasukan mengenai pengaturan tentang hubungan kerja, baik di sektor formal maupun informal, atau segera diganti dengan Undang-Undang Ketenagakerjaan yang baru. Hal ini mengingat beberapa pasal yang ada dalam Undang-Undang Nomor 13 Tahun 2003 tentang Ketenagakerjaan telah dilakukan uji materiil oleh Mahkamah Konstitusi sebanyak 11 kali, sehingga pasal-pasal yang telah diuji tersebut dinyatakan bertentangan dengan Undang-Undang Dasar Negara Republik Indonesia Tahun 1945 dan dinyatakan tidak memiliki kekuatan mengikat adalah sebagai berikut:

a. Putusan Mahkamah Konstitusi Nomor 012/PUU-I/2003 tentang pengujian Pasal 158, Pasal 159, Pasal 160 ayat (1), Pasal 170, Pasal 171, Pasal 186 Undang-Undang Nomor 13 Tahun 2003 tentang Ketenagakerjaan.

b. Putusan Mahkamah Konstitusi Nomor 115/PUU-VII/2009 tentang pengujian Pasal 120 ayat (1), ayat (2), dan ayat (3) Undang-Undang Nomor 13 Tahun 2003 tentang Ketenagakerjaan.

c. Putusan Mahkamah Konstitusi Nomor 61/PUU-VIII/2010 tentang pengujian Pasal 1 butir 22, Pasal 88 ayat (3) huruf a, Pasal 90 ayat (2), Pasal 160 ayat (3) dan ayat (6), Pasal 162 ayat (1) huruf a, Pasal 171 Undang-Undang Nomor 13 Tahun 2003 tentang Ketenagakerjaan.

d. Putusan Mahkamah Konstitusi Nomor 19/PUU/2011 tentang Pengujian Pasal 164 ayat (3) Undang-Undang Nomor 13 Tahun 2003 tentang Ketenagakerjaan.

\footnotetext{
52 Penjelasan Umum Undang-Undang Nomor 13 Tahun 2003 tentang Ketenagakerjaan.

53 Revrisond Baswir, et.al., Pembangunan Tanpa Perasaan : Evaluasi Pemenuhan Hak Ekonomi, Sosial, dan Budaya, Elsam, Jakarta, 2003, hlm. 24.
} 
e. Putusan Mahkamah Konstitusi Nomor 27/PUU/2011 tentang pengujian Pasal 65 ayat (7), dan Pasal 66 ayat (2) Undang-Undang Nomor 13 Tahun 2003 tentang Ketenagakerjaan.

f. Putusan Mahkamah Konstitusi Nomor 37/PUU/2011 tentang pengujian Pasal 155 ayat (2) Undang-Undang Nomor 13 Tahun 2003 tentang Ketenagakerjaan.

g. Putusan Mahkamah Konstitusi Nomor 58/PUU-VII/2011 tentang pengujian 169 ayat (1) huruf c Undang-Undang Nomor 13 Tahun 2003 tentang Ketenagakerjaan.

h. Putusan Mahkamah Konstitusi Nomor 100/PUU-VII/2012 tentang pengujian Pasal 96 Undang-Undang Nomor 13 Tahun 2003 tentang Ketenagakerjaan.

i. Putusan Mahkamah Konstitusi Nomor 117/PUU-VII/2012 tentang pengujian Pasal 163 ayat (1) Undang-Undang Nomor 13 Tahun 2003 tentang Ketenagakerjaan.

j. Putusan Mahkamah Konstitusi Nomor 69/PUU-VII/2013 tentang pengujian Pasal 160 ayat (3) dan ayat (7), Pasal 162 ayat (1) dan ayat (2) UndangUndang Nomor 13 Tahun 2003 tentang Ketenagakerjaan.

k. Putusan Mahkamah Konstitusi Nomor 96/PUU-VII/2013 tentang pengujian Pasal 59 ayat (7), Pasal 65 ayat (8), dan Pasal 66 ayat (4) Undang-Undang Nomor 13 Tahun 2003 tentang Ketenagakerjaan.

\section{PENUTUP}

Hukum merupakan produk politik yang memiliki karakter sebagai produk hukum yang dapat dilihat apakah berkarakter hukum responsif, seperti yang dikemukakan oleh Nonet dan Selznick atau berkarakter hukum ortodoks, seperti yang dikemukakan Marryman. Untuk mengetahui apakah Undang-Undang Nomor 13 Tahun 2003 berkarakter hukum responsif atau berkarakter hukum ortodoks, maka dalam studi ini digunakan indikator dalam proses pembuatan hukum, sifat fungsi hukum, dan kemungkinan penafsiranna. Pada produk hukum yang berkarakter responsif, proses pembuatannya bersifat partisipatif, yakni mengundang sebanyakbanyaknya partisipasi masyarakat melalui kelompok-kelompok sosial dan individu didalam masyarakat, sedangkan proses pembuatan produk hukum yang berkarakter ortodoks bersifat sentralistik dalam arti lebih didominasi oleh lembaga negara terutama pemegang kekuasaan eksekutif. Sementara itu, dilihat dari fungsinya maka hukum yang berkarakter responsif bersifat aspiratif. Artinya memuat materi-materi yang secara umum sesuai dengan aspirasi atau kehendak masyarakat yang dilayani. Sehingga produk hukum itu dapat dipandang sebagai kristalisasi dari kehendak masyarakat, sedangkan hukum yang berkarakter ortodoks bersifat positivisinstrumentalis. Artinya memuat materi yang lebih merefleksikan visi sosial dan politik pemegang kekuasaan atau memuat materi yang lebih merupakan alat untuk mewujudkan kehendak dan kepentingan program pemerintah.Jika dilihat dari segi penafsiran, maka produk hukum yang berkarakter responsif biasanya memberi sedikit peluang bagi pemerintah untuk membuat penafsiran sendiri melalui 
berbagai peraturan pelaksanaan dan peluang yang sempit itupun hanya berlaku untuk hal-hal yang betul-betul bersifat teknis, sedangkan produk hukum yang berkarakter ortodoks memberi peluang yang luas kepada pemerintah untuk membuat berbagai interpretasi dengan berbagai peraturan lanjutan yang berdasarkan visi sepihak dari pemerintah dan tidak sekedar masalah teknis. Produk hukum ortodoks biasanya cenderung memuat materi singkat dan pokok-pokok saja untuk kemudian memberi peluang yang luas bagi pemerintah untuk mengatur berdasarkan visi dan kekuatan politiknya.

\section{DAFTAR PUSTAKA}

\section{Buku}

Abdul Jalil, Teologi Buruh, LKIS Yogyakarta, Yogyakarta, 2008.

Agusmidah, Dilematika Hukum Ketenagakerjaan Tinjauan Politik Hukum, Sofmedia, Medan, 2011.

Aloysius Uwiyono, "Implikasi UndangUndang No. 13 Tahun 2003 Terhadap Iklim Investasi", Jurnal Hukum Bisnis, Volume 22 No. 5, Yayasan Pengembangan Hukum Bisnis, Jakarta, 2003.

Dwidja Priyatno, Kebijakan Legislasi tentang Sistem Pertanggungjawaban Pidana Korporasi di Indonesia, Utomo, Bandung, 2004.

Ismail Sunny, Hak Asasi Manusia, Yarsif Watampone, Jakarta, 2004.
Marsen Sinaga, Pengadilan Perburuhan di Indonesia (Tinjauan Hukum Kritis atas Undang-Undang PPHI), Semarak Cemerlang Nusa (SCN), Yogyakarta, 2006.

Mochtar Kusumaatmadja dan B. Arief Sidharta, Pengantar Ilmu Hukum (Suatu Pengenalan Pertama Ruang Lingkup Berlakunya Ilmu Hukum) Bagian I, Alumni, Bandung, 2000.

Moh. Mahfud MD., Politik Hukum di Indonesia, LP3ES, Jakarta, 2001.

Ni'matul Huda, Negara Hukum, Demokrasi \& Judicial Review, UII Press, Yogyakarta, 2005.

R. Wiyono, Garis Besar Pembahasan dan Komentar UUD 1945, Alumni, Bandung, 1976.

Revrisond Baswir, et.al., Pembangunan Tanpa Perasaan: Evaluasi Pemenuhan Hak Ekonomi, Sosial, dan Budaya, Elsam, Jakarta, 2003.

Soetandyo Wignjosoebroto, Dari Hukum Kolonial ke Hukum Nasional: Dinamika Sosial Politik dalam Perkembangan Hukum di Indonesia, RajaGrafindo Persada, Jakarta, 1994.

Sri Bintang Pamungkas, Pokok-pokok Pikiran tentang Demokrasi Ekonomi dan Pembangunan, Yayasan Daulat Rakyat, Jakarta, 1996.

Ujang Charda S., Mengenal Hukum Ketenagakerjaan Indonesia: Sejarah, 
Teori \& Praktiknya di Indonesia, Fakultas Hukum UNSUB, Subang, 2014.

,Reorientasi Reformasi Model Hukum Ketenagakerjaan dalam Kebijakan Pemerintah", Jurnal Ilmu Hukum Syiar Hukum, Vol. XIV No. 1, Fakultas Hukum UNISBA, Bandung, Maret 2012.

\section{Internet}

http://partaiburuhkarawang.blogspot. com/2011/03/karakter-undangundang-nomor-13-tahun.html, akses tanggal 21 Pebruari 2013, jam 12: 45 WIB. 